\title{
Does Hedging with Derivatives Affect Future Crash Risk?
}

\author{
Hyun-Young PARK*, Soo Yeon PARK**
}

Received: January 21, 2020 Revised: February 24, 2020 Accepted: March 6, 2020.

\begin{abstract}
The study aims to investigate the relationship between hedging with derivatives and subsequent firm-level stock price crash risk. Our sample consists of KOSPI- and KOSDAQ-listed companies from 2004 to 2014. The total firm-year observation is 4,886. We find that hedging with derivatives is related to greater possibilities of crash risk. The results suggest that the complexity of economic and financial reporting for derivatives may aggravate the company's information opacity, ultimately increasing the crash risk. We contribute to the growing body of literature on hedging with derivatives. Academics and practitioners have debated on whether or not hedging enhances transparency or rather makes the information environment more opaque. Theoretical research on the role of corporate hedging on information environment shows that hedging enhances earnings informativeness. Meanwhile, pieces of anecdotal and empirical evidence show that the economic and financial reporting complexity of derivatives can harm information transparency. Our results shed light on the question of whether and how hedging with derivatives affects information environment by examining the relationship between hedging with derivatives and crash risk. Furthermore, our findings provide useful insights for policymakers and practitioners. Specifically, our results raise a need for a more transparent disclosure on corporate hedging activities with derivatives.
\end{abstract}

Keywords : Derivatives, Hedging, Information Environment, Stock Price Crash Risk

JEL Classification Code : G10, G14, G32

\section{Introduction}

This study examines the association between hedging with derivatives and crash risk. Extant empirical studies following the agency theoretical concept of Jin and Myers (2006) argue that opaque financial reporting and information environment increase the possibilities of a stock price crash (e.g., Hutton, Marcus, \& Tehranian, 2009; DeFond, Hung, Li, \& Li, 2015; Ertugrul, Lei, Qiu, \& Wan, 2017). Meanwhile, the empirical results on the influence of corporate hedging on information environment are mixed (e.g., DaDalt, Gay, \& Nam, 2002; Manconi, Massa, \&

${ }^{*}$ First Author. Assistant Professor, School of Global Business, Anyang University, Korea. Email: hyp1103@anyang.ac.kr

${ }^{* *}$ Corresponding Author. Assistant Professor, School of Business Administration, Chung-Ang University, Korea [Postal Address: \#310-936, 47, Heukseok-ro, Dongjak-gu, Seoul, 06911, Korea] Tel. +8228206808 ,

Email: sooyeonpark@cau.ac.kr; and sypark1229@gmail.com

(c) Copyright: The Author(s)

This is an Open Access article distributed under the terms of the Creative Commons Attribution Non-Commercial License (http://Creativecommons.org/licenses/by-nc/4.0/) which permits unrestricted noncommercial use, distribution, and reproduction in any medium, permits unrestricted noncommercial use,
provided the original work is properly cited.
Zhang, 2018; Chang, Donohoe, \& Sougiannis, 2016). We provide evidence on the effect of hedging with derivatives on information environment by exploring whether and how hedging activities have an impact on crash risk.

Risk management theory argues that corporate hedging reduces firm risk and enhances firm value (e.g., Mayers \& Smith, 1982; Froot, Scharfstein, \& Stein, 1993). Although, in principle, derivatives are hedging tools that should decrease firm risk, pieces of anecdotal and empirical evidence show that the economic and financial reporting complexity of derivative contracts can harm information transparency. For instance, Chasan (2013) suggests that corporate disclosures on hedging with derivatives and application of hedge accounting are remarkably unclear; hence, investors are unable to comprehend the real risk exposure and risk management activities. Buffett (2002) is also concerned that the mark-to-market valuation of derivatives degenerates into "mark-to-myth." Meanwhile, DeMarzo and Duffie (1995) theoretically show that hedging enhances the earnings informativeness as an indication of project quality and managerial ability by alleviating extraneous noise. Several pieces of empirical evidence support their arguments. 
The competing views on the informational influence of hedging on financial markets give two opposite predictions on the relation between hedging with derivatives and crash risk. First, if hedging with derivatives makes the information environment more transparent and decreases the information asymmetry between managers and investors, then it is more difficult for managers to delay bad news. Therefore, corporate hedging activities decrease crash risk. Second, if hedging with derivatives makes the information environment more opaque, which stemmed from both the complexity of derivative contracts and managerial incentives, then it becomes easier for managers to hoard bad news, thereby leading to higher crash risk.

Examining 4,886 firm-year data in Korea for the period 2004-2014, we find that hedging with derivatives is related to greater possibilities of crash risk. These results indicate that the economic and financial reporting complexity of derivatives deteriorates earnings informativeness, making the information environment more opaque. That is, hedging increases financial reporting opportunism of managers by encouraging managers to use irrational assumptions in accounting processes or conceal significant information needed to understand them (Manconi et al., 2018), ultimately leading to greater crash risk. Moreover, endogeneity is a potential issue for any analysis of corporate hedging. To alleviate the issue, we adopt twostage least squares (2SLS) regression. The results are robust to the main results.

We contribute to the growing body of literature on derivatives and crash risk. Although DeMarzo and Duffie (1995) theoretically show that hedging enhances the earnings informativeness, academics and practitioners have debated on whether or not hedging enhances transparency or rather makes the information environment more opaque. Our results shed light on the question by examining whether and how hedging with derivatives affects crash risk. Furthermore, our findings provide useful insights for policymakers and practitioners. Practitioners indicate that corporate disclosures on hedging with derivatives are remarkably opaque that investors are often unable to comprehend the risk exposures and the impact on future cash flows and earnings. Our results raise a need for a more transparent disclosure on corporate hedging activities with derivatives.

\section{Literature Review}

\subsection{Hedging with Derivatives}

Under the perfect capital market setting of Miller and Modigliani (1958), any risk management activity should be irrelevant. However, in the real world with market imperfection, risk management activities enhance firm value (e.g., Mayers \& Smith, 1982; Froot et al., 1993). Despite the theoretical foundation, extant studies' empirical results are inconsistent. For instance, Allayannis and Weston (2001) and Graham and Rogers (2002) show that the market value of firms that are hedging with derivatives is higher than non-users. However, Jin and Jorion (2006) and Tufano (1996) find no support for the value maximization theory of hedging.

While several theoretical and empirical studies focus on the relationship between hedging with derivatives and information environment, the results are mixed. For instance, DeMarzo and Duffie (1995) show that corporate hedging enhances earnings informativeness by alleviating extraneous noise. Moreover, DaDalt et al. (2002) find that hedging with derivatives is associated with greater accuracy and dispersion of analysts' earnings forecasts. They argue that managers can curtail the noise of earnings caused by macroeconomic factors, and thus, the earnings informativeness is increased. However, Manconi et al. (2018) find that hedging is related to lower uncertainty and lower informed trading. Meanwhile, Chang et al. (2016) find that analysts cannot fully interpret the hedging activities and forecast earnings of firms with more hedged assets less accurately. They argue that financial analysts misapprehend the implications of firms' hedging activities because of the economic complexity of derivatives and the financial reporting of such economic complexity. Generally, the effect of hedging with derivatives on information environment is not clear.

\subsection{Stock Price Crash Risk}

The bulk of recent empirical studies on crash risk follows the agency theoretical concept of Jin and Myers (2006) who show that information asymmetry between managers and investors contributes to crash risk (e.g., Hutton et al., 2009; Lee \& Chae, 2018; Chae, Nakano, \& Fujitani, 2020). Information asymmetry allows managers to delay bad news over time to protect employment and maximize compensation (Kothari, Shu, \& Wysocki, 2009). When cumulative bad news is suddenly revealed in the market, stock prices continue to decrease, thereby resulting in a crash. Out of the massive body of prior studies on the determinants of crash risk, we look into the researches on the association between financial reporting and disclosure and crash risk. Hutton et al. (2009) find evidence that firms with lower quality of financial reporting are more likely to experience a subsequent crash risk. Moreover, Francis, Hasan, and $\mathrm{Li} \mathrm{(2016)}$ find that firms that engage in real earnings management tend to experience stock price crashes. Chen, Kim, and Yao (2017) argue that a higher level of earnings smoothing is related to higher crash risk. 
Meanwhile, Kim and Zhang (2016) suggest that subsequent crash risk decreases for the level of conservatism of financial reporting. Ertugrul et al. (2017) show that firms with greater 10-K file sizes and a higher ambiguity in 10Ks are related to higher crash risk. In addition, from an accounting standards perspective, DeFond et al. (2015) find that international financial reporting standards (IFRS) adoption has reduced crash risk; they argue that the results are consistent with the enhanced transparency of IFRS. In summary, prior literature shows that transparent financial reporting and information environment decreases the possibility of crash risk. In this regard, we examine whether and how hedging with derivatives affects the information environment of the firm and consequently influences crash risk.

\subsection{Hypothesis Development}

DeMarzo and Duffie (1995) theoretically show that corporate hedging enhances the earnings informativeness by eliminating extraneous noise. However, extant empirical studies on the effect of hedging are inconsistent. On the one hand, several prior studies argue that hedging with derivatives improves information environment of a firm (DaDalt et al., 2002; Chen \& King, 2014; Manconi et al., 2018). In this respect, hedging activities make the information environment more transparent, decrease the information asymmetry between managers and investors, and consequently make it difficult for managers to hoard bad news (Kim \& Zhang, 2016; DeFond et al., 2015). As a result, hedging with derivatives will be related to a decreased possibility of crash risk.

On the other hand, derivatives are exceedingly complex by nature, and the economic and financial reporting complexity leads to opaque information environment (Ryan, 2007; Bratten, Gaynor, McDaniel, Montague, \& Sierra, 2013; Chang et al., 2016). From an economic perspective, derivatives are complex because their value changes in response to the change in underlying indices. Under this economic complexity, financial reporting for derivatives is also intricate. The complex accounting standards and measurement uncertainty in applying the rules cause investors to misinterpret the implications of firms' hedging activities. In addition, opaque disclosure on corporate hedging activities deteriorates information environment (Ertugrul et al., 2017; Baimukhamedova, Baimukhamedova, \& Luchaninova, 2017), and consequently hedging allows managers to hide negative news from the scrutiny of investors (Barton, 2001; Bodnar, Hayt, Marston, \& Smithson, 1995). The economic and financial reporting complexity of hedging activities may exacerbate a firm's information opacity by enticing managers to use unreasonable assumptions in accounting treatment or to hoard significant information necessary to comprehend them (Manconi et al., 2018), thereby leading to increased crash risk.

Given these competing predictions, the impact of hedging with derivatives on crash risk is ultimately an empirical question. Therefore, the following null hypothesis is established:

Hypothesis 1: Hedging with derivatives is associated with stock price crash risk.

\section{Research Design}

\subsection{Measuring Stock Price Crash Risk}

Following Chen, Hong, and Stein (2001) and Jin and Myers (2006), we employ two major firm-specific crash risk measures to examine the association between hedging with derivatives and crash risk. We first estimate firmspecific weekly returns using the following model:

$$
\begin{aligned}
\gamma_{i, t}=\beta_{0}+\beta_{1, t} \gamma_{m, t-2}+\beta_{2, t} \gamma_{m, t-1}+\beta_{3, t} \gamma_{m, t}+\beta_{4, t} \gamma_{m, t+1} \\
+\beta_{5, t} \gamma_{m, t+2}+\beta_{6, t} \gamma_{k, t-2}+\beta_{7, t} \gamma_{k, t-1} \\
+\beta_{8, t} \gamma_{k, t+1}+\beta_{9, t} \gamma_{k, t+2}+\epsilon_{i, t}
\end{aligned}
$$

where $\gamma_{i, t}$ is the weekly return of stock $i, \gamma_{m, t}$ is the valueweighted market weekly return, and $\gamma_{k, t}$ is the valueweighted industry return based on the KSIC codes. The weekly return of firm $i$ in week $t\left(W_{i, t}\right)$ is specified as $W_{i, t}=\ln \left[1+\varepsilon_{i, t}\right]$ using residuals from model (1).

We apply NCSKEW as the first proxy measure for crash risk, which is calculated by taking the negative of the third moment of firm-specific weekly returns per year and normalized by the standard deviation of the firm-specific weekly return to the third power. Our second measure of crash risk is DUVOL. Specifically, we separated all the weeks with firm-specific weekly returns below (above) the annual mean, which are called "down" ("up") weeks for each firm $i$ over a fiscal-year period $t$. In addition, the standard deviation for each group was calculated separately, and the logarithm of the ratio of the standard deviations of "down" sample to "up" sample was computed.

\subsection{Hedging with Derivatives and Crash Risk}

To explore the impact of hedging with derivatives on future crash risk, we assess the following empirical model (2). The two measurements of crash risk, $N C S K E W_{t+1}$ and $D U V O L_{t+1}$, are employed as the dependent variables. $F X_{-} D_{t}$ and $F X_{-} A M T_{t}$ are used as the main independent variables for testing the hypothesis. Similar control 
variables were selected based on previous studies (e.g., Chen et al., 2001; Hutton et al., 2009). All variables are defined in Appendix A.

$$
\begin{aligned}
\text { CRASH }_{i, t+1}=\beta_{0} & +\beta_{1} F X_{i, t}+\beta_{2} \operatorname{SIZE}_{i, t}+\beta_{3} \text { MRET }_{i, t} \\
& +\beta_{4} \text { MB }_{i, t}+\beta_{5} L E V_{i, t}+\beta_{6} \text { BETA }_{i, t} \\
& +\beta_{7} \text { ROA }_{i, t}+\beta_{8} \text { SUMDA }_{i, t}+\beta_{9} F_{R N_{i, t}} \\
& +\beta_{10} \text { BOD }_{i, t}+\beta_{11} M_{N G S H R_{i, t}} \\
& +\beta_{12} \text { CRASH }_{i, t}+\text { YEAR DUMMY } \\
& + \text { INDUSTRY DUMMY }
\end{aligned}
$$

\section{Empirical Results}

\subsection{Sampling}

The sample consists of KOSPI- and KOSDAQ-listed companies from 2004 to 2014, excluding 2010 and 2011. The years 2010 and 2011 are omitted from the sample period because the accounting standard transited from KGAAP to K-IFRS during that period. The total firm-year observation is 4,886 . We collected financial data from TS2000 provided by the Korea Listed Companies Association and Fn-Guide. Table 1 provides sample selection procedures. We winsorized each continuous variable at the top (bottom) $1 \%$ yields to prevent influential observations.
Table 1: Sample Selection

\begin{tabular}{|c|c|}
\hline Sample selection criteria & No. of firm-years \\
\hline Total listed firms in the sample for 2009-2013 & 6,301 \\
\hline Less & $(153)$ \\
\hline $\begin{array}{c}\text { (1) Firms with non-December 31 fiscal year- } \\
\text { end }\end{array}$ & $(413)$ \\
\hline (2) Financial institutions & $(217)$ \\
\hline $\begin{array}{c}\text { (3) Firms without purpose of derivative use } \\
\text { and derivative contract value data }\end{array}$ & $(632)$ \\
\hline $\begin{array}{c}\text { (4) Firms without other necessary data for } \\
\text { control variables }\end{array}$ & 4,886 \\
\hline Total & \\
\hline
\end{tabular}

\subsection{Descriptive Statistics}

Table 2 presents the summary statistics of the variables used in the regressions. The mean values of crash risk measures $N C S K E W_{t+1}$ and $D U V O L_{t+1}$ are -0.435 and -0.227 , respectively, similar to values found in the study of Park and Song (2018) that used Korean firms' data. The mean value of $F X_{-} D_{t}$ indicates that $24.4 \%$ of the sample are hedging financial risk exposures with derivatives. The mean value for the contract amounts of derivatives $\left(F X \_A M T_{t}\right)$ is 0.002 , indicating that the contract value of derivatives scaled by the total assets is $2 \%$. Untabulated statistics show that the mean value for the contract amounts of derivatives $\left(F X_{-} A M T_{t}\right)$ for the firms using derivatives is 0.010 , indicating that the contract value of derivatives scaled by the total assets is $10 \%$.

Table 2: Descriptive Statistics of the Main Variables

\begin{tabular}{|c|c|c|c|c|c|c|c|}
\hline Variables & Mean & Std. Dev. & Min & $\mathbf{2 5 \%}$ & Median & $\mathbf{7 5 \%}$ & Max \\
\hline NCSKEW $_{\mathrm{t}+1}$ & -0.435 & 0.798 & -2.849 & -0.859 & -0.366 & 0.035 & 1.851 \\
\hline DUVOL $_{\mathrm{t}+1}$ & -0.227 & 0.364 & -1.153 & -0.465 & -0.220 & 0.014 & 0.676 \\
\hline FX_D $_{\mathrm{t}}$ & 0.244 & 0.429 & 0.000 & 0.000 & 0.000 & 0.000 & 1.000 \\
\hline FX_AMT $_{\mathrm{t}}$ & 0.002 & 0.013 & 0.000 & 0.000 & 0.000 & 0.000 & 0.101 \\
\hline SIZE $_{\mathrm{t}}$ & 17.240 & 0.672 & 16.140 & 16.668 & 17.211 & 17.821 & 18.403 \\
\hline MRET $_{\mathrm{t}}$ & 0.002 & 0.009 & -0.023 & -0.003 & 0.002 & 0.007 & 0.026 \\
\hline MB $_{\mathrm{t}}$ & 1.921 & 2.240 & 0.216 & 0.755 & 1.236 & 2.090 & 15.006 \\
\hline LEV $_{\mathrm{t}}$ & 0.432 & 0.197 & 0.033 & 0.276 & 0.435 & 0.577 & 0.885 \\
\hline BETA $_{\mathrm{t}}$ & 0.720 & 0.528 & -0.605 & 0.354 & 0.698 & 1.065 & 2.043 \\
\hline ROA $_{\mathrm{t}}$ & 0.029 & 0.079 & -0.327 & 0.006 & 0.034 & 0.068 & 0.218 \\
\hline SUMDA $_{\mathrm{t}}$ & 0.343 & 0.656 & 0.010 & 0.075 & 0.129 & 0.227 & 3.050 \\
\hline FRN $_{\mathrm{t}}$ & 0.106 & 0.144 & 0.000 & 0.006 & 0.039 & 0.153 & 0.643 \\
\hline BOD $_{\mathrm{t}}$ & 0.148 & 0.106 & 0.000 & 0.077 & 0.133 & 0.200 & 0.500 \\
\hline MNGSHR $_{\mathrm{t}}$ & 0.065 & 0.110 & 0.000 & 0.000 & 0.001 & 0.100 & 0.501 \\
\hline
\end{tabular}




\subsection{Regression Analysis Results}

Columns (1), (2), (5), and (6) of Table 3 show the multivariate analysis results on whether the crash risk is impacted by hedging with derivatives. $F X D_{t}$ and $F X \_A M T_{t}$ variables exhibit significant positive coefficients at $1 \%$ level, implying that firms hedging with derivatives experience significantly higher future crash risk. This result suggests that the complexity of economic and financial reporting for derivatives may aggravate the company's information opacity, ultimately increasing the crash risk.

Table 3: The Effect of Hedging with Derivatives on Stock Price Crash Risk

\begin{tabular}{|c|c|c|c|c|c|c|c|c|}
\hline \multirow{2}{*}{ Variable } & (1) & (2) & (3) & (4) & (5) & (6) & (7) & (8) \\
\hline & \multicolumn{4}{|c|}{ NCSKEW $_{t+1}$} & \multicolumn{4}{|c|}{ DUVOL $_{t+1}$} \\
\hline Intercept & $\begin{array}{c}-1.185^{* * *} \\
(-4.07)\end{array}$ & $\begin{array}{c}-1.211^{* * *} \\
(-4.15)\end{array}$ & $\begin{array}{c}-1.370^{* * *} \\
(4.22)\end{array}$ & $\begin{array}{c}-1.777^{* * *} \\
(4.56)\end{array}$ & $\begin{array}{c}-0.588^{* * *} \\
(-4.50)\end{array}$ & $\begin{array}{c}-0.598^{* * *} \\
(-4.52)\end{array}$ & $\begin{array}{c}-0.702^{* * *} \\
(-4.50)\end{array}$ & $\begin{array}{c}-0.944^{* * *} \\
(-5.04)\end{array}$ \\
\hline$F X \_D_{t}$ & $\begin{array}{c}0.115^{* * *} \\
(4.18)\end{array}$ & & & & $\begin{array}{c}0.046^{* * *} \\
(3.59)\end{array}$ & & & \\
\hline FX_AMT & & $\begin{array}{c}2.729^{* * *} \\
(2.95)\end{array}$ & & & & $\begin{array}{c}1.130^{* * *} \\
(2.69)\end{array}$ & & \\
\hline RES_FX_D & & & $\begin{array}{c}0.888^{* * *} \\
(2.75)\end{array}$ & & & & $\begin{array}{c}0.527^{* * *} \\
(3.39)\end{array}$ & \\
\hline RES_FX_AMT & & & & $\begin{array}{c}29.262^{* * *} \\
(2.74)\end{array}$ & & & & $\begin{array}{c}17.338^{* * *} \\
(3.38)\end{array}$ \\
\hline SIZE $_{t}$ & $\begin{array}{l}0.028^{*} \\
(1.71)\end{array}$ & $\begin{array}{l}0.029^{*} \\
(1.80)\end{array}$ & $\begin{array}{l}0.043^{* *} \\
(2.28)\end{array}$ & $\begin{array}{c}0.068^{* * *} \\
(2.88)\end{array}$ & $\begin{array}{l}0.013^{*} \\
(1.81)\end{array}$ & $\begin{array}{l}0.014^{*} \\
(1.88)\end{array}$ & $\begin{array}{l}0.022^{* *} \\
(2.52)\end{array}$ & $\begin{array}{c}0.038^{* * *} \\
(3.31)\end{array}$ \\
\hline $\mathrm{MRET}_{\mathrm{t}}$ & $\begin{array}{c}5.994^{* * *} \\
(3.54)\end{array}$ & $\begin{array}{c}5.965^{* * *} \\
(3.56)\end{array}$ & $\begin{array}{l}6.919^{* * *} \\
(3.750)\end{array}$ & $\begin{array}{c}6.919^{* * *} \\
(3.73)\end{array}$ & $\begin{array}{c}2.837^{* * *} \\
(3.68)\end{array}$ & $\begin{array}{c}2.841^{* * *} \\
(3.69)\end{array}$ & $\begin{array}{c}3.391^{* * *} \\
(3.79)\end{array}$ & $\begin{array}{c}3.391^{* * *} \\
(3.77)\end{array}$ \\
\hline $\mathrm{MB}_{\mathrm{t}}$ & $\begin{array}{l}0.010^{* *} \\
(2.02)\end{array}$ & $\begin{array}{l}0.089^{*} \\
(1.71)\end{array}$ & $\begin{array}{c}0.024^{* * *} \\
(3.00)\end{array}$ & $\begin{array}{l}0.010^{*} \\
(1.87)\end{array}$ & $\begin{array}{c}0.005^{* *} \\
(2.01)\end{array}$ & $\begin{array}{l}0.004^{*} \\
(1.70)\end{array}$ & $\begin{array}{c}0.013^{* * *} \\
(3.40)\end{array}$ & $\begin{array}{l}0.005^{*} \\
(1.89)\end{array}$ \\
\hline $\mathrm{LEV}_{\mathrm{t}}$ & $\begin{array}{l}-0.083 \\
(-1.30)\end{array}$ & $\begin{array}{l}-0.046 \\
(-0.73)\end{array}$ & $\begin{array}{c}-0.554^{* * *} \\
(-2.70)\end{array}$ & $\begin{array}{c}-0.316^{* *} \\
(-2.48)\end{array}$ & $\begin{array}{l}-0.046 \\
(-1.57)\end{array}$ & $\begin{array}{l}-0.028 \\
(-1.01)\end{array}$ & $\begin{array}{c}-0.335^{* * *} \\
(-3.39)\end{array}$ & $\begin{array}{c}-0.194^{* * *} \\
(-3.16)\end{array}$ \\
\hline $\mathrm{BETA}_{\mathrm{t}}$ & $\begin{array}{l}0.004 \\
(0.20)\end{array}$ & $\begin{array}{l}0.010 \\
(0.45)\end{array}$ & $\begin{array}{c}0.034^{* * *} \\
(1.34)\end{array}$ & $\begin{array}{l}0.034 \\
(1.34)\end{array}$ & $\begin{array}{l}-0.005 \\
(-0.52)\end{array}$ & $\begin{array}{l}-0.001 \\
(-0.11)\end{array}$ & $\begin{array}{l}0.012 \\
(1.00)\end{array}$ & $\begin{array}{l}0.012 \\
(0.99)\end{array}$ \\
\hline $\mathrm{ROA}_{t}$ & $\begin{array}{l}0.136 \\
(0.83)\end{array}$ & $\begin{array}{l}0.166 \\
(1.01)\end{array}$ & $\begin{array}{l}0.038 \\
(0.21)\end{array}$ & $\begin{array}{l}0.038 \\
(0.21)\end{array}$ & $\begin{array}{l}0.048 \\
(0.65)\end{array}$ & $\begin{array}{l}0.061 \\
(0.82)\end{array}$ & $\begin{array}{l}-0.016 \\
(-0.18)\end{array}$ & $\begin{array}{l}-0.016 \\
(-0.18)\end{array}$ \\
\hline SUMDA $_{t}$ & $\begin{array}{l}0.019 \\
(1.16)\end{array}$ & $\begin{array}{l}0.018 \\
(1.10)\end{array}$ & $\begin{array}{l}0.020 \\
(1.11)\end{array}$ & $\begin{array}{l}0.020 \\
(1.11)\end{array}$ & $\begin{array}{l}0.008 \\
(1.11)\end{array}$ & $\begin{array}{l}0.008 \\
(1.07)\end{array}$ & $\begin{array}{l}0.008 \\
(1.00)\end{array}$ & $\begin{array}{l}0.008 \\
(1.00)\end{array}$ \\
\hline $\mathrm{FRN}_{\mathrm{t}}$ & $\begin{array}{c}0.554^{* * *} \\
(6.64)\end{array}$ & $\begin{array}{c}0.543^{* * *} \\
(6.44)\end{array}$ & $\begin{array}{l}0.538 \\
(5.87)\end{array}$ & $\begin{array}{c}0.537^{* * *} \\
(5.85)\end{array}$ & $\begin{array}{c}0.269^{* * *} \\
(7.10)\end{array}$ & $\begin{array}{c}0.265^{* * *} \\
(6.92)\end{array}$ & $\begin{array}{c}0.254^{* * *} \\
(5.78)\end{array}$ & $\begin{array}{c}0.254^{* * *} \\
(5.75)\end{array}$ \\
\hline $\mathrm{BOD}_{\mathrm{t}}$ & $\begin{array}{l}0.000 \\
(0.00)\end{array}$ & $\begin{array}{l}-0.031 \\
(-0.29)\end{array}$ & $\begin{array}{l}-0.028 \\
(-0.25)\end{array}$ & $\begin{array}{l}-0.028 \\
(-0.25)\end{array}$ & $\begin{array}{l}0.006 \\
(0.12)\end{array}$ & $\begin{array}{l}-0.007 \\
(-0.16)\end{array}$ & $\begin{array}{l}-0.006 \\
(-0.10)\end{array}$ & $\begin{array}{l}-0.005 \\
(-0.10)\end{array}$ \\
\hline MNGSHR $_{\mathrm{t}}$ & $\begin{array}{l}-0.198^{*} \\
(-1.90)\end{array}$ & $\begin{array}{c}-0.195^{*} \\
(-1.87)\end{array}$ & $\begin{array}{c}-0.198^{*} \\
(-1.77)\end{array}$ & $\begin{array}{l}-0.199^{*} \\
(-1.76)\end{array}$ & $\begin{array}{l}-0.085^{*} \\
(-1.81)\end{array}$ & $\begin{array}{l}-0.084^{*} \\
(-1.78)\end{array}$ & $\begin{array}{l}-0.084 \\
(-1.56)\end{array}$ & $\begin{array}{c}-0.084 \\
(1.55)\end{array}$ \\
\hline $\begin{array}{l}\text { NCSKEW }_{t} \\
\left(\text { DUVOL }_{t}\right)\end{array}$ & $\begin{array}{c}0.104^{* * *} \\
(7.05)\end{array}$ & $\begin{array}{c}0.105^{* * *} \\
(7.10)\end{array}$ & $\begin{array}{c}0.101^{* * *} \\
(6.24)\end{array}$ & $\begin{array}{c}0.100^{* * *} \\
(6.21)\end{array}$ & $\begin{array}{c}0.115^{* * *} \\
(7.51)\end{array}$ & $\begin{array}{c}0.116^{* * *} \\
(7.72)\end{array}$ & $\begin{array}{c}0.109^{* * *} \\
(6.28)\end{array}$ & $\begin{array}{c}0.109^{* * *} \\
(6.26)\end{array}$ \\
\hline $\begin{array}{c}\text { Year and Industry } \\
\text { dummy }\end{array}$ & \multicolumn{8}{|c|}{ Included } \\
\hline Adjusted $\mathrm{R}^{2}$ & $5.68 \%$ & $5.52 \%$ & $4.70 \%$ & $4.66 \%$ & $4.91 \%$ & $4.86 \%$ & $6.48 \%$ & $6.32 \%$ \\
\hline $\mathrm{N}$ & \multicolumn{8}{|c|}{4,886} \\
\hline
\end{tabular}

Endogeneity is a potential issue for any analysis of corporate hedging. This concern is attenuated in our study because the independent variable is not a firm choice but the result of market participants' beliefs and trading behavior. However, several other traits of the firm would trigger a firm's decision of the use of derivative contracts. 
To alleviate the problem, we adopt Heckman's (1979) 2SLS regression. In the first stage, we employed various variables that could affect hedging with derivatives following prior studies (e.g., Nance, Smith \& Smithson, 1993; Ban \& Kim, 2004). In the second stage, we used the residuals of $F X_{-} D_{t}$ and $F X A M T_{t}$ variables from the first stage as independent variables of interest. The results are shown in Columns (3), (4), (7), and (8) of Table 3. The findings corroborate that our empirical results are robust to endogeneity concerns.

\section{Conclusion}

This study investigates the impact of hedging with derivatives on firm-level crash risk. Examining 4,886 firmyear data in Korea for the period 2009-2014, we show that hedging with derivatives increases the possibility of future crash risk. The results indicate that the economic and financial reporting complexity of derivatives decreases the quality of information environment, thereby resulting in a higher possibility of crash risk. In addition, we find that our main results are robust to 2 SLS regression. We shed new lights on the literature on corporate hedging activities with derivatives and information environment. Moreover, we expand the evidence of the determinants of crash risk. In addition, our results provide useful insights for policymakers and practitioners.

\section{References}

Allayannis, G., \& Weston, J. P. (2001). The use of foreign currency derivatives and firm market value. The Review of Financial Studies, 14(1), 243-276.

Baimukhamedova, A., Baimukhamedova, G., \& Luchaninova, A. (2017). Financial disclosure and the cost of equity capital: The empirical test of the largest listed companies of Kazakhstan. Journal of Asian Finance, Economics and Business, 4(3), 5-17.

http://dx.doi.org/10.13106/jafeb.2017.vol4.no3.5

Ban, H. J., \& Kim, J. K. (2004). The determinants of hedging with derivatives. Korea Business Review, 33(1), 25-49.

Barton, J. (2001). Does the use of financial derivatives affect earnings management decisions? The Accounting Review, $76(1), 1-26$.

Bodnar, G. M., Hayt, G. S., Marston, R. C., \& Smithson, C. W. (1995). Wharton survey of derivatives usage by US nonfinancial firms. Financial Management, 24(2), 104-114.

Bratten, B., Gaynor, L. M., McDaniel, L., Montague, N. R., \& Sierra, G. E. (2013). The audit of fair values and other estimates: The effects of underlying environmental, task, and auditor-specific factors. Auditing: A Journal of Practice \& Theory, 32(sp1), 7-44.

Buffett, W. (2002). Chairman's letter to the shareholders of Berkshire Hathaway. Retrieved February 1, 2019, from http://www.berkshirehathaway.com/letters/2002pdf.pdf.

Chang, H. S., Donohoe, M., \& Sougiannis, T. (2016). Do analysts understand the economic and reporting complexities of derivatives? Journal of Accounting and Economics, 61(2-3), 584-604.

Chasan, E. (2013). Investors seek more transparency on corporate hedging, derivatives exposures. Wall Street Journal. Retrieved January 16, 2019, from https://blogs.wsj.com/cfo/2013/01/16/investors-seek-moretransparency-on-corporate-hedging-derivatives-exposures/.

Chen, C., Kim, J. B., \& Yao, L. (2017). Earnings smoothing: Does it exacerbate or constrain stock price crash risk? Journal of Corporate Finance, 42, 36-54.

Chen, J., \& King, T. H. D. (2014). Corporate hedging and the cost of debt. Journal of Corporate Finance, 29, 221-245.

Chen, J., Hong, H., \& Stein, J. C. (2001). Forecasting crashes: Trading volume, past returns, and conditional skewness in stock prices. Journal of Financial Economics, 61(3), 345-381.

DaDalt, P., Gay, G. D., \& Nam, J. (2002). Asymmetric information and corporate derivatives use. Journal of Futures Markets, 22(3), 241-267.

DeFond, M. L., Hung, M., Li, S., \& Li, Y. (2015). Does mandatory IFRS adoption affect crash risk? The Accounting Review, 90(1), 265-299.

DeMarzo, P. M., \& Duffie, D. (1995). Corporate incentives for hedging and hedge accounting. Review of Financial Studies, 8(3), 743-771.

Ertugrul, M., Lei, J., Qiu, J., \& Wan, C. (2017). Annual report readability, tone ambiguity, and the cost of borrowing. Journal of Financial and Quantitative Analysis, 52(2), 811-836.

Francis, B., Hasan, I., \& Li, L. (2016). Abnormal real operations, real earnings management, and subsequent crashes in stock prices. Review of Quantitative Finance and Accounting, 46(2), $217-260$.

Froot, K. A., Scharfstein, D. S., \& Stein, J. C. (1993). Risk management: Coordinating corporate investment and financing policies. The Journal of Finance, 48(5), 1629-1658.

Graham, J. R., \& Rogers, D. A. (2002). Do firms hedge in response to tax incentives? The Journal of Finance, 57(2), 815-839.

Heckman, J. J. (1979). Sample selection bias as a specification error. Econometrica, 153-161.

Hutton, A. P., Marcus, A. J., \& Tehranian, H. (2009). Opaque financial reports, R2, and crash risk. Journal of Financial Economics, 94(1), 67-86.

Jin, Y., \& Jorion, P. (2006). Firm value and hedging: Evidence from US oil and gas producers. The Journal of Finance, 61(2), 893-919.

Jin, L., \& Myers, S. C. (2006). R2 around the world: New theory and new tests. Journal of Financial Economics, 79(2), 257292.

Kim, J. B., \& Zhang, L. (2016). Accounting conservatism and stock price crash risk: Firm-level evidence. Contemporary Accounting Research, 33(1), 412-441.

Kothari, S. P., Shu, S., \& Wysocki, P. D. (2009). Do managers withhold bad news? Journal of Accounting Research, 47(1), 241-276.

Lee, A. Y., \& Chae, S. J. (2018). The effect of management disclosure and analysis on the stock crash risk: Evidence from 
Korea. Journal of Asian Finance, Economics and Business, 5(4), 67-72.

http://doi.org/10.13106/jafeb.2018.vol5.no4.67

Manconi, A., Massa, M., \& Zhang, L. (2018). The informational role of corporate hedging. Management Science, 64(8), 38433867.

Mayers, D., \& Smith, C. W. (1982). On the corporate demand for insurance. Foundations of Insurance Economics. Dordrecht, Netherlands: Springer.

Miller, M., \& Modigliani, F. (1958). The cost of capital, corporate finance and the theory of investment. American Economic Review, 48, 261-297.

Nance, D. R., Smith Jr, C. W., \& Smithson, C. W. (1993). On the determinants of corporate hedging. The Journal of Finance, 48(1), 267-284.
Park, S. Y., \& Song, Y. (2018). The effect of ownership structure on future stock price crash risk: Korean evidence. Journal of Applied Business Research, 34(2), 355-368.

Ryan, S. G. (2007). Financial Instruments and Institutions: Accounting and Disclosure Rules. New York, NY: John Wiley \& Sons.

Chae, S. J., Nakano, M., \& Fujitani, R. (2020). Financial Reporting Opacity, Audit Quality and Crash Risk: Evidence from Japan. Journal of Asian Finance, Economics and Business, $7(1), \quad 9-17$. https://doi.org/10.13106/jafeb.2020.vol7.no1.9

Tufano, P. (1996). Who manages risk? An empirical examination of risk management practices in the gold mining industry. The Journal of Finance, 51(4), 1097-1137. 


\section{Appendix A}

Definition of variables

\begin{tabular}{|c|c|}
\hline Variable & Definition \\
\hline \multicolumn{2}{|c|}{ Dependent variables } \\
\hline \multirow[t]{15}{*}{ NCSKEW $_{t+1}$} & Negative skewness of firm-specific weekly returns \\
\hline & $\begin{array}{l}\begin{array}{l}\text { Natural logarithm of the ratio of the standard deviations of down-week to up-week firm-specific weekly } \\
\text { returns }\end{array} \\
\end{array}$ \\
\hline & An indicator variable that equals 1 if a firm hedges with derivatives, and 0 otherwise \\
\hline & Contract amounts of derivatives divided by total assets in year $t$ \\
\hline & Natural logarithm of total assets of a firm in year $\mathrm{t}$ \\
\hline & Average of firm-specific weekly returns in year $\mathrm{t}$ \\
\hline & Market values normalized by total equities in year $\mathrm{t}$ \\
\hline & Ratio of total liabilities to total assets in year $\mathrm{t}$ \\
\hline & Beta index of the market model during the prior 60 months \\
\hline & Operating income scaled by total assets in year $\mathrm{t}$ \\
\hline & Three-year moving sum of the absolute value of annual performance-adjusted discretionary accruals in year $t$ \\
\hline & $\begin{array}{c}\text { An indicator variable that equals } 1 \text { if auditing is conducted by one of the Big } 4 \text { accounting firms, and } 0 \\
\text { otherwise }\end{array}$ \\
\hline & Percentage of equity ownership by foreign investors \\
\hline & Percentage of outside directors on corporate boards \\
\hline & Percentage of equity ownership by CEO \\
\hline
\end{tabular}

